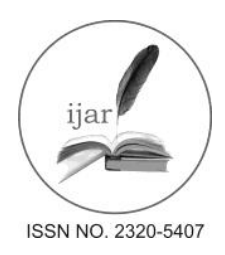

Journal homepage: http://www.journalijar.com Journal DOI: 10.21474/IJAR01

RESEARCH ARTICLE

\section{INTERNATIONAL JOURNAL}

OF ADVANCED RESEARCH

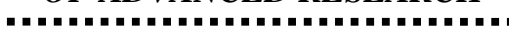

\title{
BIOREMEDIATION OF HYDROCARBON - A REVIEW.
}

\author{
Anwesha Banerjee ${ }^{1}$, Atanu Roy ${ }^{2}$, Suvakshan Dutta ${ }^{1}$ and ${ }^{*}$ Sandhimita Mondal ${ }^{1}$. \\ 1. Department of Microbiology, Techno India University, Salt Lake, Kolkata 700091. \\ 2. Department of Biotechnology, Techno India University, Salt Lake, Kolkata 700091.
}

\section{Manuscript Info \\ Manuscript History: \\ Received: 14 April 2016 \\ Final Accepted: 18 May 2016 \\ Published Online: June 2016 \\ Key words: \\ Hydrocarbon, Bioremediation, oil \\ spills, leakages, phytoremediation. \\ *Corresponding Author}

Sandhimita Mondal.

\begin{abstract}
Hydrocarbons are compounds made up of carbon and hydrogen. Hydrocarbon pollution has far reaching implications for both terrestrial and aquatic ecosystem as well as in the atmosphere. It has been a problem ever since the use of fossil fuels began. The unprecedented increase of populations and also industrial development in both developing and developed countries during the last century have increased the threat of rampant pollution in the environment. Oil spills in oceans, leakages in pipelines carrying crude oil and gas exploration activities, production, refining, transport and storage of hydrocarbons like petroleum and its byproducts also contribute to the pollution. These together are threatening the lives of animals and native microbiological population in land, air and water surfaces and sub-surfaces. The process of bioremediation by microorganisms those that break down hydrocarbons can be used to purge the environment of these persistent pollutant particles. Not only microorganisms but plants too help in bioremediation (phytoremediation). This paper focuses on an updated review on bioremediation of hydrocarbon pollution by various techniques.
\end{abstract}

Copy Right, IJAR, 2016.. All rights reserved.

\section{Introduction:-}

Hydrocarbons like petroleum and its products have become a major energy source in this century, its use in industry and daily life have increased ten-fold to that used previously leading to hydrocarbon contamination of both soil and water. Every year about 35 million barrels of oil is ferried across the oceans, making the aquatic environment vulnerable to pollution from oil spills, leakages that threaten the aquatic or marine life all over (Macaulay., 2014). Contamination of soil with oil spills is another major concern, contaminated soil is a serious, often lethal hazard to the health of humans, and it causes pollution of ground water, environmental problems, decreases overall productivity of agricultural land (Thapa et al., 2012). Such incidents of pollution in both soil and water has become quite frequent nowadays. These pose severe immediate and long-term influence since many hydrocarbon constituents are toxic in nature. These pollutants persist in soil and water for a very long time often decades. In India recent oil spill incident occurred in Mumbai 2010, which left vast areas of the Arabian sea polluted with leaked oil from the ship, another such incident occurred in Sunderbans (Bangladesh) in 2014 where 350 tons of oil was spilled into the river Sela spread over $70 \mathrm{sqr} \mathrm{km}$, thereby threatening the mangrove forest of Sunderbans as well as the various species of flora and fauna in that region. India has a vast network of pipeline that transports petroleum oil. Oil spills due to leakages from joints of pipelines, accidents of tankers are common yet devastating to the surroundings. Accumulation of these toxic pollutants in plants and animal tissues may cause mutation and death in many cases. Not only petroleum but Diesel too contains mixtures of highly concentrated compounds that are toxic, which have highly harmful and fatal effect on humans and animals (Jain \& Bajpai., 2012 ). 
The major effects of hydrocarbon pollutions are :

* Global Warming.

- Loss of delicate species of animals that are on the verge of extinction or endangered, due to toxic contamination of oceans, land, and air.

* Reduced productivity of agricultural land if the soil is contaminated with spilled oil.

* The death of fishes in oceans, lakes, ponds, rivers due to toxicity and lack of oxygen when the water bodies are contaminated with petroleum contaminants, thus causing economic loss.

* Aromatic hydrocarbons may lead to cancer.

* Inhalation of hydrocarbon can cause irritation in the respiratory tract, and they can cause the onset of asthma and other allergies.

* Most hydrocarbons are carcinogenic to lungs.

* PAHs can cause prenatal defects, reduced birth weight, developmental deficits.

To remove the pollutants from the contaminated site of soil and water, several physicochemical methods have been developed for the decontamination of the site. Such methods are not only highly expensive but also labor intensive, and there is an inherent risk of aggravating the situation and spreading of the pollution (Salleh et al., 2003). Other common technologies used are evaporation, burying, dispersion and washing (Das \& Chandran., 2010), but as is the problem with these techniques they often lead to incomplete decomposition of the pollutants. Thus, a process of natural, yet simple and cost-effective method of hydrocarbon removal is desired in today's world.

\section{Bioremediation:-}

Bioremediation is the process of utilizing living organisms, microorganisms to degrade pollutants and contaminants from the environment and transform them into less toxic form. Bioremediation is based on the ability of a microorganism to degrade the hydrocarbons into components that can be taken up by other micro-organisms as a nutrient source or can be safely returned to the environment. Degraded organic components are converted into water, carbondioxide and other inorganic compounds. Not only microbes but plants too help in biodegradation of hydrocarbons. An effective bioremediation requires enzymatic attack by microorganisms to convert pollutants into harmless products. Environmental parameters should be optimum to help the microorganisms to grow and degrade the pollutants at a rapid rate (de la Cueva et al., 2016).

There are limitations to this technology also, for example, chlorinated hydrocarbons or other high aromatic hydrocarbons are almost resistant to microbial degradation or are degraded at a really slow pace. But bioremediation techniques are somewhat economical and can be widely implemented. Most of the techniques in bioremediation are aerobic in nature, but anaerobic processes are also being developed to help degrade pollutants in oxygen deficit areas (Franchi et al., 2016).

There are two types of bioremediation strategies:

In Situ Bioremediation:-

This method of bioremediation is cost effective and causes less disturbance to the surrounding area of the contaminated site. In situ method is mainly used for soil contamination due to oil spills. Thus, it is limited by the depth up to which microorganisms can help degrade pollutants. Mostly up to $30-60 \mathrm{~cm}$ of depth in soil have been reached for the process of bioremediation.

\section{Bioventing:-}

This is common in situ method of bioremediation which involves supplying air at a low flow rate and provides much-needed oxygen and nutrients by wells to stimulate the microorganisms in the contaminated site. Through this method, it is determined that volatilization of the contamination is avoided, and they do not spread. It is an effective method for simple hydrocarbons.

\section{In situ biodegradation:-}

In this process oxygen and nutrients are added to the soil by means of an aqueous solution that circulates through the contaminated soil, the solution contains water-containing nutrients, oxygen and electron acceptors to stimulate the microorganism. This method is used for soil and groundwater treatment. 


\title{
Biosparging:-
}

Biosparging is a method which involves infused air to the water table below and increases the percentage of oxygen available to the microorganism, under low pressure and enhances the biodegradation capability of microorganism. It increases the mingling in the saturated zone, it also increases the interaction between the soil and groundwater. The ease of handling and installing air injectors makes this process feasible, and the flexibility of the design helps to implement it on a variety of contaminated sites.

\section{Ex-situ bioremediation:- Biopiles:-}

This is a combination of landfarming and composting. In this method engineered cells are constructed in a composted piles in a well-aerated condition. Moreover, this technique is refined from landfarming method and controls the spread of contamination by volatilization and leaching. This technique is used for treatment of contamination of the surface of spilled hydrocarbon pollutants mainly petroleum products. Biopiles helps grow indigenous aerobic and anaerobic microorganisms.

Apart from biopiles, Landfarming and composting are two other methods of Ex-situ bioremediation.

\section{Bioreactors:-}

Bioreactors are used for treating hydrocarbon pollutants in a safe and simple way. It is used for Ex situ bioremediation where slurry reactors or aqueous reactors are used for treating contaminated water or soil. The contaminants are kept in a containment vessel and using various apparatus mixing is done at a three-phase system that is, solid, liquid and gas. The slurry formed due to this mixing help the biodegradation of the pollutants and also increases the biomass (which contains the microorganisms). The only limitation of this technique is that the pretreatment that has to be done before the contaminated soil or water can be placed in the bioreactors.(Vidali, 2001)

Both In Situ and Ex Situ methods of bioremediation are effective, but the rate and extent of the effectiveness are higher in bioreactor system because of the safety (no leaching or volatilization because of the containment chamber of bioreactors), they are more controllable and predictable in giving results.

\section{Components Of Hydrocarbon Pollution \& Microbial Degradation:-}

\section{Alkanes:-}

Alkanes constitute one of the most percentages of petroleum-related pollution, and they are generally easily degraded, especially those that have shorter chains which lower their hydrophobicity. Straight chain alkanes (C10C24 ) are the most rapidly degraded (Atlas, 1981). Strains of microorganisms like A. calcoaceticus and Nocardioforms demonstrates good growth in n-alkane having 30 and 40 carbon atoms respectively (Radwan et al.,1999). But the degradation of alkanes decreases with increase in the number of carbon chain-length. This reduces the solubility of the alkanes in an aqueous medium (de la Cueva et al., 2016).

\begin{abstract}
Alkane degradation:-
In some species of Pseudomonas sp. And Acinetobacter sp., it is seen that the degradation of alkane begins with the oxidation of terminal methyl group which as a result yields an alcohol. This alcohol is dehydrogenated by the action of an aldehyde to form carboxylic acid. The carboxylic acid can be metabolized further by the $\beta$-oxidation pathway of fatty acids. (May \& katapodis,1990; Lal \&Khanna , 1996). Some Rhodococcus sp. Oxidizes n-alkanes by both the terminal and sub terminal pathways, in which alkanes are oxidized by the action of a monooxygenase and yields a secondary alcohol, which is then converted to a ketone and then to a fatty acid (Whyte et al., 1998). Some microorganisms like A. calcoaceticus S19, where the compound octadecane was first converted to octadecanol and then finally to octadecanoic acid (Bajpai et al., 1998).

\section{Aromatic hydrocarbons:-}

Aromatic hydrocarbon present in most hydrocarbon pollutants are as follows: Benzene, Xylenes, ethylbenzene, toluene. Together they are called BTEX. The BTEX compounds are a real threat when they leak into the ground water, and these compounds are non-oxygenated monoaromatic having high water solubility that helps them too diffuse in the water and contaminate drinking water sometimes even migrate to the subsurface of water bodies nearby. Bradley and Chapelle (1995) showed a new technique which could be used for in situ bioremediation of pollution caused by hydrocarbons in ground water systems in cold regions. In this method rapid mineralization of toluene in aerobic conditions was demonstrated in petroleum contaminated regions of Alaska, where temperatures
\end{abstract}


are less than $5^{\circ} \mathrm{C}$. Rates of microbial activity was compared to that of regions having mean temperature of $20^{\circ} \mathrm{C}$.the result showed that the biodegradation rate in ground water of cold regions is not lower than that of temperate regions. Other bioremediation of hydrocarbon pollution was demonstrated in shallow aquifers near natural gas producing sites (Gieg et al., 1999). All BTEX compounds were seen to be biodegraded. The changes were monitored for four years, under sulfate -reducing conditions. Toluene was seen to be degraded in a methanogenic conditions. Weiner and Lovley(1998) proposed a new technique to add benzene-oxidizing sulfate reducers to aquifers, when they noted a persistence of benzene contaminants in aquifers near sulfate reduction zones. Using thermophilic aerobic microorganisms to detoxify liquid effluent streams was a process shown by Lugowski et al. (1997) the strains of Pseudomonas species was predominant in the culture mixture. These were seen to degrade a wide range hydrocarbons with an aromatic side chain, for example, phenols, aniline, lindane, benzene-compounds (benzothiazole) and other combinations of such hydrocarbons. Chen and Taylor(1995, 1997a) isolated two thermophilic strains Thermus aquaticus and Thermus sp. which can degrade BTEX compounds co-metabolically. Chen and Taylor (1997b) had also isolated two anaerobic consortia, which consisted of unidentified coccus which could grow on all BTEX compounds as sole carbon source.

\section{Degradation of aromatic hydrocarbons:-}

Degradation of benzene occurs with the oxidation of molecules in a triple-enzyme system, at first two hydroxyl groups, are added to the molecule forming a cis-dihydriol, this is then dehydrogenated to result in catechol. Catechol has aromatic ring which could be cleaved using two oxidative methods, The meta-cleavage or the Ortho-cleavage to produce semi-aldehyde or muconic acid respectively (Muller, 1992: Salleh et al., 2003).

Degradation of Toluene is relatively easier than that of other BTEX compounds since it degrades rapidly in aerobic conditions and this is studied extensively in Pseudomonas sp.(Hubert et al.,1999; Lee \&Gibson,1996; Salleh et al., 2003). Other microorganisms that show relatively important capability to degrade toluene are Mycobacterium, Rhodococcus, Acinetobacter Azoarcus and so on.(Juteau et al., 1999 ). Different microorganisms degrade toluene in different manner toluene can either be oxidized to benzoic acid, oxidation occurs at the methyl group, this kind of degradation is seen in Pseudomonas putida mt-2 and P. aeruginosa or on the aromatic ring to yield a dihydrodiol in a cis-configuration, this kind of degradation is seen in P. mendocina.

Degradation of xylenes are characterized by oxidation at the methyl group just like that of toluene, which then results in formation of toluic acid, tolualdehydes , methylbenyl- alcohols and methyl catechols (Davey \&Gibson, 1974).

\section{Phenol:-}

Phenol is a major pollutant that is released in to the environment from oil industries as a common constituent of wastewaters. Bioremediation of phenol with microorganisms are influenced by the temperature in which phenol containing wastewaters are treated. Onysko et al(2000);Margesin\&Schinner(2001) states that the effect of temperature $\left(10-25^{\circ} \mathrm{C}\right)$ is appropriate for the treatment of wastewater by psychrotrophic Pseudomonas putida. According to Pillis \& Davis (1985), another psychrotrophic P. putida removed a variety of phenolic compounds under aerobic and $\mathrm{pH}$-neutral conditions, where the temperatures range from 1 to $35^{\circ} \mathrm{C}$. It was suggested that this strain could be used in a variety of waste treatment processes like, activated sludge treatments, trickling filter systems, outdoor lagoons, the strain could work alone or in combination with other microorganisms. Bioremediation products of the phenolic compounds can then be discharged in to the river streams after processing. Some thermophilic bacilli produce phenol hydroxylases (Müller et al., 1998)which seem to differ in different strains of microorganisms.

\section{Polycyclic Aromatic Hydrocarbons (PAH):-}

Polycyclic aromatic hydrocarbons (PAH) consists of about sixteen types that are considered as priority pollutants (US EPA, 1993; Macaulay 2014).Naphthalene, phenanthrene, and pyrene are mostly studied PAH are known to be frequent soil contaminants. In cold climates biodegradation of PAH are not extensively studied but cold tolerant strains like Sphingomonas or Pseudomonas spp., that can degrade naphthalene, phenanthrene and fluorene are isolated. It was seen that the strains could also degrade BTEX compounds (Aislabie et al. 2000). PAHs degradation by thermophilic bacterias is very little studied, Müller et al. (1998) isolated strains of thermophilic microorganisms that can degrade naphthalene, phenanthrene, and anthracene. It was seen that these microorganisms have a different metabolites than those of mesophilic microorganisms. Some even had a different pathway for degradation of 
hydrocarbon compounds than that of the mesophilic microbes for example, Bacillus thermoleovorans which degraded naphthalene at $60^{\circ} \mathrm{C}$.

\section{Degradation of PAHs:-}

PAH catabolism starts by oxidation of the compounds to a dihydrodiol by a multi-enzyme system. Dihydroxylated intermediates are then processed by the ortho-cleavage or meta-cleavage pathway to yield catechols and then these catechols are converted into compounds that can be used as tricarboxylic acid cycle intermediates (Van der Meer et al., 1992).Naphthalene is the simplest form of PAHs, which is easily degraded by microorganisms. It is first oxidized to a cis- 1,2-dihydroxy-1,2-dihydronapthalene, by adding oxygen atoms into the aromatic molecule. This is then converted to 1,2-dihydroxynapthalene, cleavage of this compound yields salicyaldehyde and pyruvate. Salicylaldehyde then is oxidized to salicylate and then to catechol(Cerniglia, 1984). Thermophilic Bacillus thermoleovorans, have a different pathway of naphthalene degradation where it produces intermediates such as 2,3dihydroxynapthalene , 2-carboxynnamic acid, benzoic acid and phthalic acid(Annweiller et al.,2000). According to Cerniglia and Heitcamp (1989), the biodegradability of the PAHs is inversely related to the number of fused benzene rings. The persistence of PAHs with low molecular weight are due to their low solubility to water and resonance energy of their structures (Cerniglia, 1992). The three- ring phenanthrene molecule can persist from 16126 days while a five ring benzo- pyrene may persist from 299 to more than 1400 days (Shuttleworth \& Cerniglia, 1995). Fluranthrene is a high molecular weight PAH, a seven-member consortium of microorganisms was made that can utilize this as a sole carbon and energy source (Mueller et al., 1989). The process of Co-metabolism helped to transform and convert other high molecular weight PAH by microorganisms that showed growth on fluranthrene. Pyrene too was seen to be metabolized by a variety of microorganisms by different pathways.

\section{Bioremediation by Genetically Engineered Microorganisms:-}

In most common circumstances in an oil-polluted sites, the indigenous microorganism is unable or do not act their full capability to degrade the pollutants, thus the need of genetically engineered or modified microorganisms (GEMs) that can increase the yield of breakdown of the pollutants.Genetically engineered microorganisms (GEMs) have shown great potential in bioremediation of hydrocarbon contaminated sites, soil-groundwater and activated sludge environments. In this technique appropriate genes for production of a protein or enzymes are inserted into the microorganism genome or as a plasmid, the gene when it is expressed produces those enzymes and proteins which degrade the contaminant (Jain et al, 2010c). GEMs have a wide research opportunity and it has important implications. Timmis and Pieper(1999) showed that microorganisms can be engineered in such a manner that the rate limiting steps in known metabolic pathways can be inserted and increases the amount of degradation of hydrocarbon pollutants. Sometimes even new pathways could be engineered and inserted in microorganisms when existing metabolic pathways are not able to degrade the pollutants. The first GEM to be released for field trial was designed by University of Tennessee in collaboration with Oak Ridge National Laboratory (Sayler et al., 1999), they released Pseudomonas fluorescens (strain HK44GEM) in a contaminated soil site, and this strain was incorporated with Vector pUTK21 which is a naphthalene catabolic plasmid (King et al., 1990). This strain was also seen to have a property of bioluminescence which is due to a transposon-based lux gene fused with a promoter for naphthalene catabolic genes (Chatterjee \& Meighen, 1995), thus whenever this strain is activated to degrade the hydrocarbon pollutants it gives bioluminescence, and this can also be considered as a reporter gene for naphthalene availability and its degradation.

Plasmids play an important role in incorporating such genes in bacterias. Chakrabarty et al (1973) incorporated a plasmid that can degrade octane. Plasmids containing genes to degrade naphthalene (Dunn\& Gunsalus, 1973), toluene (Williams \& Murray, 1974) and camphor (rheinwald e al., 1973) are few examples. UV-irradiated microorganisms like Pseudomonas aeruginosa TDJ2M and Pseudomonas putida TDJ6M showed an increase in the activity of enzyme named $\mathrm{C} 23 \mathrm{O}$ when compared to their wild type relatives. Another isolated strain Pseudomonas mallei TDJ4M showed an increase in the monooxygenase activity. Genetically engineered microorganisms are also used in bioreactors for example waste water from industries containing diesel oil are treated in rotating biological contactor, where oil degrading microbes like Burkholderia cepacia and oil tolerant microorganisms which are phototrophic are added for greater yield. The future of GEMs is still unclear due to its high maintenance cost and due to the skeptical view on genetically engineered microorganisms by the public. However, researches are still being carried out to provide safe genetically engineered microorganisms which can help towards a better and cleaner environment. 
There are certain environmental requirements for an effective bioremediation:

Table 1:- Parameters for microbial growth and hydrocarbon degradation.

\begin{tabular}{|l|l|l|}
\hline Parameters & $\begin{array}{l}\text { Condition required for microbial } \\
\text { activity }\end{array}$ & $\begin{array}{l}\text { Optimum value for an oil } \\
\text { degradation }\end{array}$ \\
\hline Soil moisture & $25-28 \%$ of water holding capacity & $30-90 \%$ \\
\hline Soil pH & $5.5-8.8$ & $6.5-8.0$ \\
\hline Oxygen content & $\begin{array}{l}\text { Aerobic, minimum air-filled pore } \\
\text { space of 10\% }\end{array}$ & $10-40 \%$ \\
\hline Nutrient content & N and P for microbial growth & $\mathrm{C}: \mathrm{N}: \mathrm{P}=100: 10: 1$ \\
\hline Temperature $\left({ }^{\circ} \mathrm{C}\right)$ & $15-45$ & $20-30$ \\
\hline Contaminants & Not too toxic & $\begin{array}{l}\text { Hydrocarbons 5-10\% of dry weight } \\
\text { of soil }\end{array}$ \\
\hline Heavy metals & Total content 2000 ppm & $700 \mathrm{ppm}$ \\
\hline Type of soil & Low clay or silt content & -- \\
\hline
\end{tabular}

(Source: Vidali (2001))

Table 2:- Advantages and Disadvantages of Bioremediation.

\begin{tabular}{|c|c|}
\hline ADVANTAGES & DISADVANTAGES \\
\hline $\begin{array}{l}\text { 1. Bioremediation is a natural process; it is widely } \\
\text { accepted by the public as an effective way to } \\
\text { remove hydrocarbon waste. The biodegraded } \\
\text { compounds are harmless and can be } \\
\text { incorporated in the environment (carbon } \\
\text { dioxide, water, and biomass.) }\end{array}$ & $\begin{array}{l}\text { B. Bioremediation process is limited to } \\
\text { compounds that are biodegradable. Not all } \\
\text { hydrocarbon pollutants are biodegradable or } \\
\text { susceptible to degradation by microorganisms. } \\
\text { Example - chlorinated hydrocarbons }\end{array}$ \\
\hline $\begin{array}{l}\text { 2. Bioremediation can be used for degrading wide } \\
\text { variety of pollutants. This technique eliminates } \\
\text { any future liability with the contaminants. }\end{array}$ & $\begin{array}{l}\text { b. There are some concerns regarding the waste } \\
\text { product that may be more toxic than that of the } \\
\text { original product, thus harm the environment } \\
\text { more. }\end{array}$ \\
\hline $\begin{array}{l}\text { 3. Transferring contaminants may cause leaching } \\
\text { and further contamination, bioremediation } \\
\text { helps to degrade the pollutants on the site } \\
\text { without causing additional hazard. }\end{array}$ & $\begin{array}{l}\text { c. The growth of microorganisms for the } \\
\text { bioremediation of the pollutant site is often } \\
\text { very specific and demanding, the factors } \\
\text { affecting the growth of microorganisms have to } \\
\text { optimum for effective degradation by microbes. }\end{array}$ \\
\hline $\begin{array}{l}\text { 4. Bioremediation method ensures that the waste } \\
\text { from the biodegradation can be incorporated } \\
\text { into the environment and does not have to be } \\
\text { carried off-site for disposal. }\end{array}$ & $\begin{array}{l}\text { d. Sites containing many different types of } \\
\text { contaminants in various phases (solid, liquid, } \\
\text { gas), which needs special treatment, or a } \\
\text { combination of special microorganisms either } \\
\text { native or genetically engineered. }\end{array}$ \\
\hline $\begin{array}{l}\text { 5. It is relatively inexpensive than other } \\
\text { techniques used for clean-up of hazardous } \\
\text { waste products. }\end{array}$ & $\begin{array}{l}\text { e. It is a time-consuming process and may need } \\
\text { extra pre-treatment before they can be degraded } \\
\text { by microorganisms (excavation, incineration). } \\
\text { Which makes this process tedious. }\end{array}$ \\
\hline
\end{tabular}

(Source: Vidali (2001))

\section{Strategies For Removal Of Hydrocarbon Contamination:-}

Life as a whole is maintained in a fragile and delicate biological balance. Microorganism plays an important role in almost every aspect of life. Using microorganism to remove the hydrocarbon pollutants from the site of pollution may be a better way to reclaim the polluted area. This process is called bioremediation. Biodegradation of hydrocarbons by microorganisms is the metabolic ability to transform organic pollutants to a less harmful and non hazardous compounds that can be degraded further and incorporate into the biogeochemical cycles. The use of bioremediation may be defined as using microorganisms or other biological elements to remove and detoxify the environment, in a non-invasive and cost-effective way. Presently the techniques used to remove oil spill contaminations are land-fill burials and incinerations for safe disposal. Others were pyrolysis, gasification that is more efficient but in most cases they the by-products have some negative shock on the environment. The thermal 
and chemical approach that is used for removing the pollutants has limited effectiveness and there is always a probability of recontamination.

There are two main methods of oil spill bioremediation using microorganisms:

\section{Bioaugmentation:-}

Where known oil-degrading bacteria are added to help and supplement the existing microbial population. In this method microorganism that can either be indigenous or genetically modified, are added to the site of contamination and bioremediation begins. This method is very effective where the native soil microorganism is unable to degrade the hydrocarbon pollutants.

\section{Biostimulation:-}

Where the indigenous microorganism are stimulated to grow with addition of growth factors like nutrients. Sometimes effective remediation is not possible for indigenous microorganisms in normal circumstances thus they have to be stimulated by optimizing the surrounding environment of the contaminated site. So by adding nutrient, oxygen, electron acceptor the existing population is stimulated. The stimulants are added to the subsurface through injection wells.

Other forms of treatment of the oil contaminated sites are:

\section{Land Farming:-}

A process where oil contaminated soil is taken and then they are spread over a bed, where it is stimulated by fertilizers to maximize the activity of microorganisms and enhance their chances of hydrocarbon degradation. The soil is rotated at a regular interval. The site specifications are a 3 feet distance between the surface and ground water table, the slope of the land not exceeding 8\%. This is an Ex-situ method of bioremediation

\section{Composting:-}

This is an Ex-situ method of bioremediation. In this method the contaminated soil is added to organic substances like agricultural waste, manure. These are returned stimulate the microorganisms to degrade the hydrocarbon pollutants.

\section{Anaerobic degradation:-}

The process of adding urea and ammonia, like fertilizers, are used in the bioremediation of oil spills, in such a method oxygen demand can go high due to the oxidation of ammonia, there may be sites where addition of oxygen is not feasible or not possible, thus in these sites microorganisms those that grow in anaerobic environment are used for bioremediation of oil-spill contaminated sites.

\section{Phytoremediation: Bioremediation by Plants:-}

Phytoremediation is a new technology which utilizes living green plants for removal, degradation or containment of pollutants in soil, water (both surface and groundwater), sludge and sediments. It is a low cost cleanup technique by using solar energy via plants. It is very useful for sites that are shallow with low levels of pollutants and sites where vegetation is used as a final closure to the polluted site. Phytoremediation is gaining popularity due to its aesthetic advantages and long-term applicability where maintaining microorganisms for a long term is not feasible. The use of this technique is mostly a secondary or polishing in situ treatment that is done with a limited disturbance to the surrounding and minimizes the threat of spreading the pollutants. Elimination of transportation is another advantage of this technique.

Microbial digestion of complex hydrocarbons is limited and has met a low amount success, but the process of vegetation based biodegradation shows a high potential for accumulating, immobilizing, and transforming persistent hydrocarbon pollutants. Plants act as filters and metabolize complex compounds for its growth. The term "phytoremediation" was coined in 1991, and this technique can be used to get rid of hydrocarbon pollutants from both soil and water sources. 
Types of phytoremediation techniques based on the fate of contaminant:-

Phytoextraction or Phytoaccumulation:-

This process is used by plants for accumulation of contaminants in the roots and shoots or leaves, usually metals from the contaminated sites are accumulated that can be either taken up by the plants or they could be transported for disposal.

\section{Phytotransformation or Phytodegradation:-}

This process is characterized by the uptake of the organic pollutants from soil or water or sediments and then they are transformed into more stable and less toxic state. It also transforms them into a less mobile state so that they do not spread to other locations.

\section{Phytostabilization:-}

This is a technique where the plants curtail the mobility and migration of pollutants; those that are leachable are absorbed into the plant cavity and bound so that they can form a less toxic stable mass.

\section{Rhizodegradation or phytodegradation:-}

It is a process of degradation or breakdown of contaminants through the activity in the rhizosphere. The proteins and enzymes secreted by plants and microbes such as bacteria, yeast, fungi help to degrade the contaminants. It also represents the symbiotic relationship between plants and microorganisms, where the plant provides shelter and nutrients and microorganisms help break complex compounds in the soil.

Rhizofiltration:- This water based technique of remediation where plants take up contaminants by its roots; it is very useful for contamination of wetlands and estuaries.

Table 3:- Techniques of Phytoremediation.

\begin{tabular}{|c|c|c|}
\hline Technique & Plant Mechanism & Surface Medium \\
\hline Phyto-extraction & $\begin{array}{l}\text { Uptake and concentration of metal } \\
\text { via direct uptake into the plant tissue } \\
\text { with subsequent removal of the } \\
\text { plants }\end{array}$ & Soils \\
\hline Phyto-transformation & $\begin{array}{l}\text { Plant uptake and degradation of } \\
\text { organic compounds }\end{array}$ & Surface water, ground water \\
\hline Phyto-stabilization & $\begin{array}{l}\text { Root exudates cause metal to } \\
\text { precipitate and become less } \\
\text { available }\end{array}$ & Soils, groundwater, mine tailing \\
\hline Phyto-degradation & $\begin{array}{l}\text { Enhances the microbial degradation } \\
\text { in rhizosphere }\end{array}$ & $\begin{array}{l}\text { Soils, groundwater } \quad \text { within } \\
\text { rhizosphere }\end{array}$ \\
\hline Rhizofiltration & Uptake of metals into plant roots & Surface water and water pumped \\
\hline Phyto-volatilization & $\begin{array}{l}\text { Plants evaporate or transpirate } \\
\text { selenium, mercury, and volatile } \\
\text { hydrocarbon }\end{array}$ & Soils and groundwater \\
\hline Vegetative cap & $\begin{array}{l}\text { Rainwater is transpired by plants to } \\
\text { prevent leaching contaminants from } \\
\text { disposal sites }\end{array}$ & Soils. \\
\hline
\end{tabular}

(Source: Bioremediation. An overview M. Vidali. (2001))

\section{Conclusion:-}

Hydrocarbon pollution removal is a real world problem, wide range of hydrocarbons contaminate the environment. A better understanding of the biodegradation mechanisms of the microorganisms is needed and is of utmost significance that will help transform pollutants into less toxic and harmful by-products that can be incorporated in to the environment without any disruptions. Microorganisms aided elimination of spilled oil from soil and water surfaces and sub-surfaces is a very cost effective and simple process that can be popularized for bioremediation. Plants also contribute towards bioremediation of hydrocarbon pollutions by utilizing the components of pollutants as a source of energy for itself and also broken down pollutants into less toxic form are taken up by rhizosphere microorganisms. Genetically modified microorganisms that can help to remove petroleum, naphthalene, toluene, 
benzene and other contaminants form a newer aspect of research with broad implications. The use of Genetically Modified Microorganisms helps to introduce better enzyme system, pathway for efficient degradation of hydrocarbons, inorganic pollutants. But the use of genetically modified microbes is under public scrutiny and thus more awareness of public is required for better implementation of this new technology. Indigenous microorganisms are preferred they perform adequately but often not to their full capability. The study of the pathways, factors influencing the growth, microbial metabolism will help to improve the factors to stimulate and manipulate the microorganisms for better result. Based on this review paper it may be considered that using natural tools like microorganism and plants are better strategies for hydrocarbon remediation.

\section{References:-}

1. Aislabie J, Foght J and Saul D. (2000). Aromatic hydrocarbon-degrading bacteria from soil near Scott Base, Antarctica. Polar Biol. 23: 183-188.

2. Andreolli, M., Albertarelli, N., Lampis, S., Brignoli, P., Khoei, N. S., \& Vallini, G. (2016). Bioremediation of diesel contamination at an underground storage tank site: a spatial analysis of the microbial community. Worl J. Microbiol Biotechnol. 32(1): 1-12.

3. Annweiler E, Richnow H. H, Antranikian G, Hebenbrock S, Garms C, Frankie S, Francke W, and Michaelis W. (2000). Naphthalene Degradation and Incorporation of NaphthaleneDerived Carbon into Biomass by the Thermophile Bacillus thermoleovorans. App. Environ. Microbio. 66(2): 518-523.

4. Bajpai $\mathbf{U}$ et al. (1998). Mineralization of $\left[{ }^{14} \mathrm{C}\right]$ octadecane by Acinetobacter calcoaceticus S19. Can J Microbiol. 44: 681-686.

5. Bamforth, S. M., \& Singleton, I. (2005). Bioremediation of polycyclic aromatic hydrocarbons: current knowledge and future directions. Journal of Chemical Technology and Biotechnology, 80(7): 723-736.

6. Barnsley E.A. (1975). The Induction of the Enzymes of Naphthalene Metabolism in Pseudomonads by Salicylate and 2-Aminobenzoate. J. Gen. Microbio. 88: 193-196.

7. Bradley P M and Chapelle F H. (1995). Rapid toluene mineralization by aquifer microorganisms at Adak, Alaska: implications for intrinsic bioremediation in cold environments. Environ. Sci. Technol. 29: $2778-2781$.

8. Cerniglia, C. E. (1984). Microbial metabolism of polycyclic aromatic hydrocarbons. Adv. Appl. Microbiol. 30: 31-71.

9. Cerniglia, C. E. (1992). Biodegradation of polycyclic aromatic hydrocarbons. Biodegradation. 3: 351-368.

10. Cerniglia, C. E., and Heitkamp M. A. (1989). Microbial degradation of polycyclic aromatic hydrocarbons (PAH) in the aquatic environment, pp. 41-68. In U. Varanasi (ed.), Metabolism of polycyclic aromatic hydrocarbons in the aquatic environment. CRC Press, Inc., Boca Raton, Fla.

11. Cerniglia, C. E., and M. A. Heitkamp. (1990). Polycyclic aromatic hydrocarbon degradation by Mycobacterium. Methods Enzymol. 188: 148-153.

12. Chakrabarty, A. M. (1972). Genetic basis of the biodegradation of salicylate in Pseudomonas. J. Bacteriol. 112: 815-823.

13. Chakrabarty, A. M., and I. C. Gunsalus. (1970). Transduction and genetic homology between Pseudomonas species putida and aeruginosa. J. Bacteriol. 103: 830-832.

14. Chakrabarty, A. M., C. F. Gunsalus, and I. C. Gunsalus. (1967). Transduction and the clustering of genes in the fluorescent pseudomonads. Proc. Nat. Acad. Sci. U.S.A. 60: 168-175.

15. Chatterjee J and Meighen E.A. (1995). Biotechnological Applications Of Bacterial Bioluminescence (lux)Genes. Photochem. Photobio. 62(4):641-650.

16. Chaturvedi, R., Prakash, J., \& Awasthi, G. (2016). Microbial Bioremediation: An Advanced Approach for Waste Management.

17. Chen C.I, Taylor R.T (1997b). Thermophilic biodegradation of BTEX by two consortia of anaerobic bacteria. Appl Microbiol Biotechnol 48:121-128.

18. Chen C.I, Taylor R.T. ( 1995). Thermophilic biodegradation of BTEX by two Thermus species. Biotechnol Bioeng 48:614-624.

19. Covino, S., Fabianová, T., Křesinová, Z., Čvančarová, M., Burianová, E., Filipová, A. \& Cajthaml, T. (2016). Polycyclic aromatic hydrocarbons degradation and microbial community shifts during co-composting of creosote-treated wood. J. hazar mater. 301:17-26.

20. Das N and Chandran P.( 2011). Microbial degradation of petroleum hydrocarbon contaminants: an overview, SAGE-Hindawi access to research Biotechnology research international, pp 1-13.

21. Davey J. F. and Gibson D. T. (1974) . Bacterial Metabolism of p-and m -xylene, J bacterial, $119: 923-929$. 
22. de la Cueva, S. C., Rodríguez, C. H., Cruz, N. O. S., Contreras, J. A. R., \& Miranda, J. L. (2016). Changes in Bacterial Populations During Bioremediation of Soil Contaminated with Petroleum Hydrocarbons. Water, Air, \& Soil Pollution, 227(3): 1-12.

23. Dunn N. W. \& Gunsalus I.C. (1973). Transmissible plasmid coding early enzymes of naphthalene oxidation in Pseudomonas putida. J Bacteriol 114: 974-979.

24. Eckford R, Cook F.D, Saul D, Aisalabie J and Foght J. (2002). Free-living Heterotrophic Nitrogen Fixing Bacteria Isolated from Fuel-Contaminated Antartic Soils. Appl. Environ. Microbiol. 68(10): 5181-5185.

25. Franchi, E., Agazzi, G., Rolli, E., Borin, S., Marasco, R., Chiaberge, S. and Barbafieri, M. (2016). Exploiting hydrocarbon-degrader indigenous bacteria for bioremediation and phytoremediation of a multi-contaminated soil.Chemical Engineering \& Technology.

26. Ghazali F.M, Rahman R, Salleh A.B, Basri M. (2004). Biodegradation of hydrocarbons in soil by microbial consortium. Int. Biodeter Biodegr 54: 61-67.

27. Gieg L.M, Kolhatkar R.V, McInerney M.J, Tanner R.S, Harris S.H Jr, Sublette K.L, Suflita J.M. (1999). Intrinsic bioremediation of petroleum hydrocarbons in a gas condensate-contaminated aquifer. Environ Sci Technol 33:2550-2560.

28. Heitkamp M.A, Franklin W and Cerniglia C.E. (1988). Microbial Metabolism of Polycyclic Aromatic Hydrocarbons: Isolation and Characterization of a Pyrene-Degrading Bacterium. App Environ Microbiol. pp. 2549-2555.

29. Hubert A, Wenzel KD, Engelwald W, Schürmann G. (2001). Accelerated solvent extraction - more efficient extraction of POPs and PAHs from real contaminated plant and soil samples. Review of Analytical Chemistry 20:101-144.

30. Jain P.K., Gupta V.K., Gaur R.K, Bajpai V., Gautam N. and Modi D.R. (2010c). Fungal Enzymes: Potential Tools of Environmental Processes. In: Fungal Biochemistry and Biotechnology, Gupta, V.K., Tuohy M. and Gaur R.K. (Eds.). LAP Lambert Academic Publishing AG and Co. KG, Germany, pp 44-56.

31. Jain P.K, Bajpai V. (2012). Biotechnology of bioremediation- a review . Int J Environ Sci. 3(1): 535-549.

32. Juteau P, Larocque R, Rho D, LeDuy A. (1999). Analysis of the relative abundance of different types of bacteria capable of toluene degradation in a compost biofilter. Appl Microbiol Biotechnol 52: 863-868.

33. King J.M.H., DiGrazia P.M., Applegate B., Burlage R.and Sanseverino J. (1990). Rapid, sensitive bioluminescent reporter technology for naphthalene exposure and biodegradation. Science, 249, 4970, pp 778-781.

34. Lal B\& Khanna S. (1996). Mineralization of $\left[{ }^{14} \mathrm{C}\right]$ octacosane by Acinetobacter alcoaceticus S30. Can $\mathrm{J}$ Microbiol, 42: 1225-1231.

35. Lee K, Gibson DT. (1996). Toluene and ethylbenzene oxidation by purified naphthalene dioxygenase from Pseudomonas sp. strain NCIB 9816-4.App Environ Microbio. 62(9): 3101-3106.

36. Lugowski AJ, Palamteer GA, Boose TR, Merriman JE. (1997). Biodegradation process for detoxifying liquid streams. Patent US5656169, August 12.

37. Macaulay, B.M. (2015). Understanding the behaviour of oil-degrading micro-organisms to enhance the microbial remediation of spilled petroleum. Appl. Ecol. Environ. Res., 13(1): 247-262

38. Margesin R (2000) Potential of cold-adapted microorganisms for bioremediation of oil-polluted alpine soils. Int Biodeterior Biodegrad 46:3-10.

39. Margesin R, Schinner F (1997a) Efficiency of indigenous and inoculated cold-adapted soil microorganisms for biodegradation of diesel oil in alpine soils. Appl Environ Microbiol 63:2660-2664

40. Margesin R, Schinner F (1997b) Bioremediation of diesel-oil-contaminated alpine soils at low temperatures. Appl Microbiol Biotechnol 47:462-468

41. Margesin R, Schinner F (1999b) Biological decontamination of oil spills in cold environments. J Chem Technol Biotechnol 74:381-389

42. Margesin R, Schinner F (eds) (1999a) Cold-adapted organisms. Springer, Berlin Heidelberg New York.

43. Margesin, R. and Schinner, F. (2001) Potential of halotolerant and halophilic microorganisms for biotechnology. Extremophiles 5:73-83.

44. Margesin, R. and Schinner, F. (2001). Biodegradation and Bioremediation of Hydrocarbons in Extreme Environments. Appl Microbiol Biotechnol 56:650-663.

45. May, S.W. and Katapodis, A.G. (1990). Hydrocarbon monooxygenases system of Psuedomonas oleovorans. Methods Enzymol , 188: 3-9.

46. Methods For Measuring The Acute Toxicity Of Effluents and Receiving Wates To Freshwater and Marine Oorganims : https://www3.epa.gov/npdes/pubs/atx.pdf 
47. Mohajeri, L., Zahed, M. A., Aziz, H. A., \& Isa, M. H. (2016). Assessment of Bioaugmentation and Biostimulation Efficiencies for Petroleum Contaminated Sediments. Environmental Energy and Economics International Research, 1: 91-99.

48. Müller P.J, Kirst G, Ruhland G, Von Storch I, Rosell-Melé A. (1998): Calibration of the alkenone paleotemperature index UK'37 based on core-tops from the eastern South Atlantic and the global ocean $\left(60^{\circ} \mathrm{N}-\right.$ $\left.60^{\circ} \mathrm{S}\right)$. Geochimica et Cosmochimica Acta, 62(10), 1757-1772.

49. Onysko, K.A., Budman, H.M., Robinson, C.W. (2000) Effect of temperature on the inhibition kinetics of phenol biodegradation by Pseudomonas putida Q5. Biotech Bio. 70(3):291-299.

50. Pillis, L.J. and Davis, L.T. (1985). Microorganism capable of degrading phenolics. Patent US4556638, December 3.

51. Radhwan , S.S., Al-Hasan, R.H., Al-Awadhi, H., Salamah, S. and Abdullah, H.M. (1999). Higher oil biodegradation potential at the Arabia Gulf coast than in water body. Marine Biology 135: 741-745.

52. Rheinwald, J.G., Chakrabarty, A.M. and Gunsalus, I.C. (1973). A Transmissible Plasmid Controlling Camphor Oxidation in Pseudomonas putida (peripheral metabolism/bacterial/episome/terpenes/genetics). Proc. Nat. Acad. Sci. USA. 70(3): 885-889.

53. Salleh, A.B., Ghazali, F.M., Rahman, R. and Basri, M. (2003). Bioremediation of petroleum hydrocarbon pollution . Indian J. Biotech. 2: 411-425.

54. Sayler, G.S. and Ripp, S. (2000). Field applications of genetically engineered microorganisms for bioremediation processes. Current Opinion in Biotechnology, 11(3): 286-289.

55. Sayler, G.S., Cox, C.D., Burlage, R., Ripp, S. and Nivens, D.E. (1999), Field Application of a Genetically Engineered Microorganism for Polycyclic Aromatic Hydrocarbon Bioremediation Process Monitoring and Control. In: Novel Approaches for Bioremediation of Organic Pollution, Fass, R., Flashner Y. and Reuveny S. (Eds.).Kluwer Academic/Plenum Publishers, New York, pp 241-254.

56. Shuttleworth, K.L. and Cerniglia, C.E. (1995). Environmental aspects of PAH biodegradation. Appl. Biochem. Biotechnol. 54:291-302.

57. Thapa, B., Kumar, K.C. A., and Ghimire, A. (2012) . A Review on bioremediation of petroleum hydrocarbon contaminants in soil. Kathmandu University Journal of Science, Engineering and Technology 8( I).

58. Timmis, K.N. and Pieper, D.H. (1999), Bacteria designed for bioremediation. Trends in Biotechnology. 17: 201-204.

59. Van der Meer, J. R., de Vos, W. M., Harayama, S., and Zehnder, A. J. (1992). Molecular mechanisms of genetic adaptation to xenobiotic compounds. Microbiol. Rev. 56: 677-694.

60. Vidali M. (2001).Bioremediation. An overview. Pure Appl. chem. 73(7):1163-1172.

61. Wang, S., Wang, X., Zhang, C., Li, F., \& Guo, G. (2016). Bioremediation of oil sludge contaminated soil by landfarming with added cotton stalks. Int Biodeter Biodegr. 106: 150-156.

62. Weiner, J.M. and Lovley, D.R. (1998) Anaerobic benzene degradation in petroleum--contaminated aquifer sediments after inoculation with a benzene-degrading enrichment. Appl Environ Microbiol 64:775-778.

63. Wenzel, K.D., Hubert, A., Manz, M., Weissflog, L., Engewald,W. and Schürmann, G. (1998). Accelerated solvent extraction of semivolatile organic compounds from biomonitoring samples of pine needles and mosses. Anal Chem. 70:4827-4835.

64. Whyte, L.G., Hawari, J., Zhou, E., Bourbonniere, L., Inniss, W.E. and Greer C.W. (1998) . Biodegradation of variable-chain-length alkanes at low temperatures by a psycotrophic Rhodococcus sp. App Environ microbiol. 64( 7) : 2578-2584.

65. Williams, P.A. and Murray, K. (1974). Metabolism of Benzoate and the Methylbenzoates by Pseudomonas putida (arvilla) mt-2: Evidence for the Existence of a TOL Plasmid. J. Bacteriol. 416-423.

66. Yan, L., Sinkko, H., Penttinen, P., \& Lindström, K. (2016). Characterization of successional changes in bacterial community composition during bioremediation of used motor oil-contaminated soil in a boreal climate. Sci Tot Environ. 542: 817-825. 